\title{
Salgın Sürecinde ve Sonrasında Öğretmenlerin Mesleki Gelişimi İçin Karma Bir Program Önerisi
}

\author{
Selçuk DOĞAN', Nihal YURTSEVEN²
}

\begin{abstract}
Öz: COVID-19 salgını her sektör ve iş alanında olduğu gibi, eğitim sektöründe de önemli etkiler bırakmıştır. Salgının ilk başladığı tarihin üzerinden uzunca bir zaman geçmiş olmasına rağmen, Türkiye' de öğretmenlere uygun yüz yüze ve çevrim içi bileşenlerin olduğu mesleki gelişim programlarının azlığı dikkat çekmekte ve var olanların da beklentileri ve ihtiyaçları karşılayacak düzeyde olmadığı görülmektedir. Mevcut araştırma, var olan boşluklara ve ihtiyaçlara yönelik bir öneride bulunma, bu alanda bakış açısı geliştirmeye katkıda bulunma ve yüz yüze ile çevrim içi bileşenlerin birbirini desteklediği bir mesleki gelişim programı sunma amacı taşımaktadır. Bu program hem fiziksel olarak yüz yüze hem eş zamanlı (senkron) hem de eş zamanlı olmayan (asenkron) etkinlikleri içinde barındırabilen, kaliteli ve etkili mesleki gelişim programlarının kuramsal temellerini içeren karma bir yapıdadır. Araştırma, salgın sürecinde ve sonrasında öğretmenlerin mesleki gelişim sürecinin nasıl şekillendirildiğinin ve bu programdan öğretmenlerin mesleki gelişimleri için gelecekte nasıl yararlanılabileceğinin betimlenmesi açısından önem arz etmektedir. Araştırmada, salgın süreci boyunca bu programın kullanılmasıyla ilgili detaylar ve örnekler verilmiş, programın uzaktan eğitim araç ve gereçleri kullanılarak nasıl uyarlanılacağına değinilmiştir.
\end{abstract}

Anahtar Sözcükler: Mesleki gelişim, Karma model, Salgın sürecinde eğitim, Öğretmen, Uzaktan eğitim, Çevrim içi öğrenme modeli

\section{A Hybrid Professional Development Program for Teachers During and After Pandemic}

\begin{abstract}
The COVID-19 pandemic has had a significant impact on the education sector, as in every sector and business field. Although it has been a long time since the first date of the pandemic, the scarcity of professional development programs in Turkey with face-to-face and online components suitable for teachers is noteworthy, and it is seen that the existing ones are not at a level to meet expectations and needs. The current study aims to make a proposal for existing gaps and needs, to contribute to developing perspectives in this area, and to offer a professional development program in which face-to-face and online components support each other. This program has a mixed structure that includes the theoretical foundations of quality and effective professional development programs, which can include both physically face-to-face, synchronous and asynchronous online activities. The study is significant in the sense that it describes how the professional development process of teachers is shaped during and after the pandemic and how this program can be used in the future for teachers' professional development. In the study, details and examples of the use of this program during the pandemic process has been given as well as how the program could be adapted using distance education tools and equipment.
\end{abstract}

Keywords: Professional development, Hybrid model, Education during pandemic, Teacher, Distance education, Online learning model

\author{
Geliş Tarihi: 27.01 .2021 \\ Kabul Tarihi: 21.05 .2021 \\ Makale Türü: Derleme Makale \\ 1 Georgia Southern University, Eğitim Fakültesi, İlköğretim ve Özel Öğretim Bölümü, ABD, e-posta: sdogan@georgiasouthern.edu, ORCID: \\ https://orcid.org/0000-0002-0527-8453 \\ ${ }^{2}$ Bahçeşehir Üniversitesi, Eğitim Bilimleri Fakültesi, İstanbul, Türkiye, e-posta: nihal.yurtseven@es.bau.edu.tr, ORCID: https://orcid.org/0000-0002-1338-4467
}


COVID-19 salgını, dünyayı, günlük hayatı ve tüm meslek gruplarını etkisi altına aldığı gibi, öğretmenlik mesleğini de önemli ölçüde etkilemiştir. Salgının tüm hızıyla yayılması sonucu dünyanın birçok yerinde eğitim ve öğretime ara verilirken, Türkiye' de çeyrek tatil öne çekilmiş ve bir haftalık tatil sonrasında uzaktan eğitime geçilmiştir. Öncesinde hiçbir hazırlık yapılmamışken, deyim yerindeyse acil bir eylem planıyla tüm kurumlarda uzaktan eğitim araçlarının sürece dahil edilmesiyle çevrim içi öğretim başlamıştır. Bu çarpıcı değişiklik, öğretmenlerin günlük rutinlerinde, öğretim biçimlerinde ve elbette mesleki gelişim süreçlerinde büyük bir değişime yol açmıştır. Dünyanın her yerinde, eğitim sistemlerinin en önemli paydaşlarından biri olan öğretmenler, salgın sürecinde daha önceleri çok fazla alışık olmadıkları ve yaygın olarak kullanmadıkları bazı dijital araçları, öğretimin ve kendi mesleki gelişimlerinin bir parçası olarak kullanmaya başlamışlardır. Yaşanan bu değişiklikler, Kaufman'ın (2020, s.1) ifade ettiği gibi, "bir uçağın tam da uçuşa geçme aşamasında parçalarını birleştirmek" gibi olmuştur ve öğretmenler, öğretimin ve mesleki gelişimlerinin devamı için baş döndürücü bir hızda yaşanan bu değişime uyum sağlamak için büyük bir çaba göstermişlerdir. Üstelik bu değişim sürecinden geçerken yararlanılabilecek bir yol haritasının dünyada bir örneği bulunmamaktaydı (Reimers, Schleicher, Saavedra ve Tuominen, 2020).

Öğretmenler eğitimde ilk müdahale ekipleridir (Ewing, 2020). Bu gerçek, salgın sürecinde yaşanan evlere kapanma ve eğitimin çevrim içi ortama taşınması sonrası, uzaktan eğitimde de ilk müdahalenin öğretmenler tarafından yapılmasını zorunlu kılmıştır. Elbette bu müdahalenin etkili bir şekilde yapılması için mesleki bir donanıma ve yeni bazı bilgi ve becerilere ihtiyaç vardır. Bu ihtiyaç, Spencer'ın (2020) ifade ettiği gibi öğretmenlerin içerik tasarımına ve salt bilgi aktarımına odaklanmak yerine, öğrencilere kendi öğrenmelerini yapılandıracakları ve kendi öğrenmelerini anlamlandırabilecekleri fırsatlar sunmaları ekseninde, salgın öncesinde 21. yüzyılda öğretmen rollerine yapılan vurguyla da paralel olarak şekillenmiştir. Şüphesiz ki salgın sürecinde yaşananlar, öğretmenlerin katıldığı mesleki gelişim programlarının da verimlilik, yararlılık ve kullanışlılık açısından sorgulanmasına yol açmıştır.

Mesleki gelişim şimdiye kadar bir salonda bir konuşmacıyı dinlemekten, meslektaşlarla etkileşim kurmaya ve tam zamanlı öğrenme deneyimleri elde etmeye kadar geniş bir perspektifte ele alınmıştır (Buckner, 2020). Fakat salgın sürecinde yaşanan durum, öğretmenlerin mesleki gelişimi için dijital bir dönüşüme ihtiyaç olduğunu, bu dönüşümün farklı çevrim içi ve karma modellere uygun bir biçimde yapılandırılması gerektiğini ortaya koymuştur (Ileria, 2017). Bu noktada Foster'ın (2020) salgın sürecini gözlemleyerek öğretmenlerin mesleki gelişimine yönelik yaptığı çıkarımlar, mesleki gelişimin bu yeni dönem sonrasındaki gerekliliklerine dikkat çekmektedir.

- Bu çıkarımlardan ilki, mesleki öğrenmelerin doğrudan öğrenci ihtiyaçları ile ilişkilendirilmesidir. Öğrenci ihtiyaçları ile ilişkilendirilen öğretmen öğrenmeleri hem önceliklerin dikkate alınmasını hem de gelişimin devamını sağlar.

- İkinci çıkarım, öğretmenlerin mesleki anlamda ihtiyaç duydukları ve istedikleri konularda öğrenmeler gerçekleştirebilmesi için onlara alan açılması ve yeterince zaman verilmesidir. Öğretmenlerin çevrim içi seminerler (webinarlar), çevrim içi kaynaklar ya da meslektaşlarla informel bağlantılar gibi farklı seçeneklerle öğrenmelerini sağlayacak bu süreç, onlara hem ilham verir hem de öğrenme fırsatı oluşturur.

- Üçüncü çıkarım, öğretmenlerin öğrenme konusunda farklı tasarım alternatifleri oluşturmalarının değerli olduğu ve bu konuda yeni bilgilere ihtiyaç duyduklarıdır. Öğretmenlerin sınırsız kaynak arasından ihtiyaçlarına uygun olanları belirleyebilmesi ve öğrenen özelliklerine uygun tasarımlar yapmaya odaklanması, etkili bir mesleki gelişim sürecinin de ayrılmaz bir parçasıdır.

Tipkı öğretimin çevrim içine taşınmasının, her yerde ve her zaman öğretme esnekliği getirmesi gibi, öğretmenlerin mesleki gelişiminin çevrim içi araçlarla zenginleştirilmesi, onların gelişiminin sürekliliği için de bir fırsat oluşturur. Buckner (2020), mesleki gelişimin herkesin bir tür öğrenme yolculuğunda olması açısından önemli olduğunu belirtmekte ve mesleki gelişimi bir ağ paylaşımı ve meslektaştan öğrenme fırsatı olarak kurgulamanın, pasif bir dinleyici olarak bir seminere katılmaktan daha faydalı olduğunu ifade etmektedir. Konu bu bakış açısıyla ele alındığında, mesleki gelişimin zaman ve mekandan bağımsız olarak, öğretmenlerin mesleki yaşamları boyunca ihtiyaç duyacakları konular ekseninde ve sosyal bir öğrenme ortamı 
Salgın Sürecinde ve Sonrasında Öğretmenlerin Mesleki Gelişimi...

kurgusuyla çevrim içi ortamda yapılandırılması önemli bir ihtiyaçtır (Baran ve Çağıltay, 2006). Son yıllarda bu tür mesleki gelişim alternatiflerine duyulan ihtiyaç, COVID-19 salgınıyla birlikte daha da belirgin hale gelmiştir.

Türkiye'de öğretmenlere yönelik geliştirilen mesleki gelişim programlarına bakıldığında, günlere yayılan atölye çalışmaları (Töre, 2017) ile etkileşimli ve pratiğe yönelik etkinlikler (Yıldız ve Arkan, 2019) gibi daha çok yüz yüze ve öğretmenlerin fiziksel bir mekanda toplanmasını gereken mesleki gelişim programlarının yaygın olduğu görünmektedir. Buna paralel olarak, OECD'nin Türkiye'deki öğretmenlere genellenebilir sonuçlar sunduğu Teaching and Learning International Survey (TALIS) çalışmasında da öğretmenlerin daha çok sadece eş zamanlı (senkron) ya da sadece eş zamanlı olmayan (asenkron) mesleki gelişim etkinliklerine katıldığı raporlanmıştır (TEDMEM, 2019). Salgınla birlikte, her ne kadar bu etkinliklerin, video konferans yoluyla yapılmaya başlandığı ve bir değişime neden olabileceği düşünülse de bu etkinliklerin sadece senkron bileşenlerle yürütülmeye çalışıldığı gözlemlenmiştir. Teknolojinin etkili kullanımıyla karma öğrenme modellerinde ve alanlarında ciddi bir büyüme söz konusuyken, öğretmenlerin mesleki gelişiminde bu modellerin nadir kullanılıyor olması, mesleki gelişim programlarının ulaşılabilir olamamasına neden olmaktadır.

Öğretmenlerin mesleki gelişimlerinin devamı ve eğitimin kalitesinin sürekliliği için etkili mesleki gelişim programlarına olan ihtiyaç çok açıktır. Öğrencilere yönelik farklı karma öğrenme modellerinin kullanıldığı çeşitli araştırmalar (Akgün ve Atıc1, 2017; Gürdoğan, 2019) olmasına rağmen, öğretmenlerin mesleki gelişiminin sağlanması için benzer alternatiflerin incelenmesi ve tanıtılması konusunda yapılmış çok az çalışma bulunmaktadır. Özellikle, Türk araştırmacıların öğretmenlerin mesleki gelişimi üzerine yaptığ1 çalışmalarda, senkron ve asenkron bileşenlerin birlikte kullanılarak, etkili mesleki gelişim programları planlama çalışmalarına nadir şekilde rastlanmaktadır. Bu boşluğa, güncel araştırmalarda dikkat çekilmektedir (Bilasa ve Taşpınar, 2017). Bilasa ve Taşpınar (2017) “hayat boyu öğrenmenin vazgeçilmez bir unsur olduğu ve bu kapsamda hazırlanan sekiz anahtar yeterliğe ilişkin modüllerin uzaktan eğitim ya da yüz yüze eğitim kapsamında kullanılmasının gerekli olduğu belirlenmiştir (p. 132)."

Salgının ilk başladığı tarihin üzerinden uzunca bir zaman geçmiş olmasına, her sektör ve iş alanında iyimser çabalar gözlemlenmesine rağmen, Türkiye'de öğretmenlere uygun yüz yüze, senkron ve asenkron bileşenlerin olduğu mesleki gelişim programlarının azlığı dikkat çekmektedir. Yapılan eğitim programlarının çoğunun sadece senkron yayınlardan oluştuğu gözlenmektedir (örneğin, SODIMER, 2021). Daha önce yapılan eğitim programların ise, var olanların beklentileri ve ihtiyaçları karşılayacak düzeyde olmadığı görülmektedir (Arslan ve Şahin, 2013). Mevcut araştırmanın amacı, yukarıda bahsedilen boşluklara ve ihtiyaçlara bir yönelik bir öneride bulunmak, bu alanda bakış açısı geliştirmeye katkıda bulunmak ve yüz yüze ile çevrim içi bileşenlerin birbirini desteklediği bir mesleki gelişim programı sunmaktır. Bu araştırma, salgın sürecinde ve sonrasında öğretmenlerin mesleki gelişim sürecinin nasıl şekillendirildiğinin ve bu programdan öğretmenlerin mesleki gelişimi için gelecekte nasıl yararlanılabileceğinin betimlenmesi açısından önem arz etmektedir.

\section{Etkili Mesleki Gelişim Programları}

Geçmiş araştırmalar, öğretmenlerde ve öğretim uygulamalarında istendik ve olumlu değişimler için, öğretmenlerin kaliteli ve etkili mesleki gelişim programlarına katılmaları gerektiğine işaret etmektedir (Penuel, Roschelle, ve Shechtman 2017). Türkçe alan yazında, etkili mesleki gelişim programları, 'Yüksek Nitelikli Mesleki Gelişim' olarak tanımlanmakta ve çoğunlukla bilimsel alt yapısını yabancı alan yazından ve araştırmalardan almaktadır (İlğan, 2013; 2020). Son 30 yılda yapılan araştırmalar ve meta analiz çalışmaları, kaliteli ve etkili programlarının, yapılandırılmış, işle bütünleşik ve temelde altı özelliğe sahip olduğunu göstermektedir (Darling-Hammond, Hyler, ve Gardner, 2017; Desimone, 2009). Bu altı özellik şu şekilde siralanabilir:

Programın içeriği: Pedagojik bilgi, alan bilgisi, pedagojik alan bilgisi ya da öğrencilerin nasıl öğrendiği birçok mesleki gelişim programının içeriğini oluşturmaktadır. Buna örnek olarak, matematik ya da fizik gibi 
konuların öğretildiği alan odaklı programlar ya da keşfetmeye dayalı öğretim yönteminin gösterildiği alana yönelik pedagojik yaklaşımların içerik olarak alındığı programlar verilebilir. Bu programlarda genellikle öğretmenler, o dersle alakalı öğrenci ödevlerini inceler, yeni bir ders planını analiz eder ya da alana yönelik pedagojik bir yaklaşımı öğrenir.

Aktif öğrenme: En temel anlamıla aktif öğrenme, geleneksel öğrenme modellerinden olan hizmet içi eğitim seminerlerinden uzaktır. Aktif öğrenme, özellikle öğretmenin nasıl öğrendiğiyle ilgilidir. Mesleki gelişim programlarında aktif öğrenme, öğretmenlerin birebir deneyimlerle tasarım, deneme ve düzeltme yapmasıdır. Öğretmenlerin yeni bir öğrenme gerçekleştirmesi ve ilgi alanlarında deneyim kazanması için programlara aktif öğrenme yaşantıları eklenmektedir. Yansıtma ve araştırma bu programlarda odak noktasıdır.

İş birliği: Putnam ve Borko (2000) öğretmenlerin mesleki uygulamalarını iş birliğine dayalı ilişkiler ya da uygulama toplulukları kapsamında etkili bir şekilde geliştirdiklerini ifade etmektedir. Başka bir ifadeyle, iş birliği, öğretmenlerin profesyonel öğrenme topluluğu oluşturarak ve grupça çalışmalar yaparak birlikte öğrenmeleridir. İş birliği küçük grupları kapsadığı kadar büyük, okul çapındaki grupları da kapsar. İş birliğinde, öğretmenler beraber ürün geliştirebilecekleri gibi, sınıf içi gözlemlerle, birbirlerine geri bildirim de sunabilir. İş birliği, aynı sınıf seviyesi, aynı bölüm ya da aynı okulda olduğunda daha etkili olduğu belirtilmektedir. İş birliğinde temel amaç, öğretmenlerin kolektif yaklaşımıyla öğretimin kalitesini artırmaktır.

Yeterli zaman ve süre: Kaliteli mesleki gelişim programları yeteri kadar zaman gerektiren ve yeterince fazla süreye yayılan programlar olarak gösterilmektedir. Kısa hizmet içi eğitimler ve seminerler bu özelliği ne yazık ki taşımamaktadır. Diğer taraftan, geleneksel ve bölümlere ayrılmış programlar ise öğretmenlerin anlamlı öğrenmesine yardımcı olmamaktadır. Mesleki gelişim, sürece yayıldığında farklı ve çoklu imkanlarla öğretmeni geliştirebilir. Yapılan meta analiz ve alan yazın çalışmaları (Darling-Hammond ve diğerleri, 2017), 20-40 saat ya da 40 saat üzeri programların, öğretmenlerin öğretim uygulamalarına olumlu etki ettiğini ortaya koymuştur.

Uzman desteği ve geri bildirim: Çoğunlukla öğretmenlerin tamamladığı çalışmalar ya da sınıf içi uygulamalara yönelik yapılan hızlı ve yapıcı yorumlardır. Etkili mesleki gelişim programlarında, geri bildirime özel zaman ayrılmakta ve bununla ilgili imkanlar bilinçli bir şekilde planlanmaktadır. Timperley, Wilson, Barrar ve Fung (2007), mesleki gelişim programlarında öğretmenlere sunulan sürekli desteğin, yeni öğrenmelerin gerçekleşmesi ve öğrenilenlerin kalıcılığının sağlanması için önemli olduğunu vurgulamaktadır. Herhangi bir beceride ustalaşma, yalnızca bilinçli ve odaklanmış uygulamalar aracılığıyla sağlanabilir ve ustalaşma sürecinin geri bildirim ile desteklenmesi gereklidir (Galaczi, Polterve Allan, 2018). Etkili mesleki gelişim programlarında uzmanlar, geri bildirim vererek öğretmenlere farkındalık kazandırmayı amaçlamaktadır. Bu tip programlarda öğretmenlere ayrıca yansıtma yapma, çalışmalarında geri bildirime dayalı değişimler yapma ve bunları açıklama fırsatı sunulmaktadır. Uzmanlar, program süresince, öğretilecek yöntemin canlandırılması ve gösterilmesini sağlamaktadır.

En iyi örneklerin sunulması: Bu özellik, öğretmenlerin mesleki gelişim programı sonunda tasarlayacakları ürünlerin en iyi halini görmesi olarak tanımlanmaktadır. En iyi örneklerin sunulması, öğretmenlerin vizyon sahibi olmaları ve kendi öğrenmelerini yönetebilmeleri için önemli görülmektedir. Üzerinde çalışılan konu hakkında canlı ve gerçek örnekler sunmak, öğretmenlerin konuyu içselleştirmesi ve beklentilerin tam olarak ne olduğunu kavrayabilmesi açısından önemlidir (Timperley ve diğerleri, 2007). Örnekler, bir dersin video kaydı, canlı ders uygulaması, bir ders planı, sınıf gözlemleri ve öğretim materyalleri üzerinden verilebilir. Öğretmenlerin bu örnekleri incelemesi için imkan sağlanması da etkili mesleki gelişim programlarının belirgin özellikleri arasında görülmektedir.

Bu özelliklere ek olarak, öğretmenlerin ve okulların hedefleriyle, mesleki gelişim programlarının hedefleri örtüşmelidir. Programların amaç ve içerikleriyle, öğretmenlerin beklentilerinin uyum içinde olması etkili mesleki gelişim programlarının özellikleri olarak gösterilmektedir. 
Salgın Sürecinde ve Sonrasında Öğretmenlerin Mesleki Gelişimi...

\section{Öğretmenlerin Mesleki Gelişiminin Karma Etkinliklerle Sürdürülmesi}

Önceden de bahsedildiği gibi, son zamanlarda özellikle salgın süreci ve sonrasında kullanılmak üzere sürdürülebilir mesleki gelişim programlarına ihtiyaç duyulmaktadır. Yukarıda bahsedilen araştırmalar içinde barındıran, uygun durumlarda kullanılmak üzere yüz yüze, senkron ve asenkron bileşenleri içeren ve karma model kategorisine girebilecek bir programın, salgın sürecinde ve sonrasında öğretmenlerin mesleki gelişimine katkı yapabileceği düşünülmektedir. Bu programın formatı, yüz yüze, senkron ve asenkron bileşenlerin, programın kazanımlarına göre karma uygulamalarla devreye sokulması üzerine oluşturulmuştur. Karma modellerde olduğu gibi, bahsi geçen programda da asenkron bileşenlerin, senkron etkinlikleri tamamlaması durumu söz konusudur (Hebebci ve Usta, 2015). Videolar, ödevler ve tartışma etkinlikleri, senkron etkinlikleri zenginleştirir. Diğer yandan, karma öğrenme ortamlarında olduğu gibi, senkron bileşenler, asenkron bileşenlerle yer değiştirebilir ve bazen birbirleri yerine kullanılabilir (Rossett, 2002). Bu programda, asenkron etkinlikler ve bu şekilde paylaşılan materyaller, ana içeriğin (dersin ya da programın) temel bir parçası olup, ek bir parça olarak düşünülmemelidir. Özetle, bahsi geçen mesleki gelişim programında yüz yüze ve çevrim içi öğrenme etkinlikleri bir arada kullanılmaktadır.

Karma mesleki gelişim programları özellikle teknolojik araçlarının etkin kullanılmasıyla birlikte yaygınlaşmaya başlamıştır (Dede, Whitehouse, Whitehouse, ve McCloskey, 2009; Ilaria, 2017). Graham (2013), 200 karma modele göre planlanan mesleki gelişim programı üzerine yaptığı araştırmada, bu programların etkili öğretim ve öğrenme ortamı sağladığını, esnek ve daha fazla öğretmene ulaşabilir olduğunu ve uygun maliyetli olduğunu ortaya koymuştur. Bir önceki bölümde referans verilen özelliklerin (aktif öğrenme, mentor desteği ve diğerleri), karma programlarda da hayata geçirilebildiği ve bu özelliklere sahip karma mesleki gelişim programlarının esnek öğrenme ortamları sunduğu belirtilmektedir (Belland, Burdo, ve $\mathrm{Gu}, 2015$; Korucu ve Kabak, 2020; Moore, Robinson, Sheffield, ve Philips, 2017; Owston ve diğerleri, 2008).

Karma mesleki gelişim programları, öğretmenlere kritik becerilerin etkili bir şekilde ve zaman kısıtlaması olmaksızın kazandırılması açısından önemlidir (Moore, Haviland, Moore, ve Tran, 2016). Çünkü karma programların çevrim içi bileşenleri, öğretmenlerin programın yüz yüze boyutunda elde ettikleri bilgileri, beceriye dönüştürmeleri aşamasında sürekli bir destek sunarak, öğretmenlerin hem kendi hızlarında hem istedikleri yerde hem de istedikleri süre zarfında çalışmalarını devam ettirmelerine olanak verir (Reimers, Schleicher, Saavedra, ve Tuominen, 2020).

Karma mesleki gelişim programlarına kullanılan etkili yöntem ve tekniklere bakıldığında, farklı örneklerin olduğu görülmektedir. Landry, Anthony, Swank ve Monseque-Bailey (2009) tarafından geliştirilen, çocuklarda erken okumaya yönelik çevrim içi uygulamaların olduğu bir mesleki gelişim programında, yansıtma, geri bildirim, içerik odaklı materyaller (okuma, erken yaşta öğrenme, dil öğretimi) kullanılmıştır. Bu programın asenkron bölümünde, videolar, tartışma forumları ve küçük grup çalışmaları yer almaktadır. Teknolojinin öğretmen öğrenmesini kolaylaştırmasını teşvik eden bu programda, öğretmenler iş birliği, aktif öğrenme ve iyi örneklerin sunumu gibi özellikleri olan öğrenme yaşantılarına katılmışlardır. Bu programda, öğretmenler örnek ders planları tasarladıktan sonra, uzmanlardan geri bildirim alarak, planlarını tekrar düzenlemişlerdir. Etkileşimli tartışma alanları sayesinde, öğretmenler yansıtma yapma imkanları bulmuştur. Bir aya yayılan ve öğretmenin en az dört saat çalışmasını gerektiren programda, katılımcı öğretmenlere, materyaller, öğretmen kılavuzları ve test geliştirme kitapları verilmiş, bunları sınıflarında kullanmaları istenmiştir. İki haftada bir yapılan canlı uzman görüşmeleri sayesinde, sınıf uygulamalarıyla ilgili paylaşım yapma imkanları sunulmuştur. Diğer bir araştırmada, Dash ve diğerleri (2012) beşinci sınıf matematik dersi için altı haftaya yayılan 70 saatlik bir mesleki gelişim programı geliştirmiştir. Bu mesleki gelişim programında içerik hem alan bilgisine hem de pedagoji bilgisine yöneliktir. Bu programda, asenkron etkinlikleri tamamlamak için öğretmenlerin aynı anda aynı yerde bulunmasına gerek yoktur. Öğrenme topluluğu modelinin kullanıldığı bu programda öğretmenler video izleme, akranlar arası tartışma etkinlikleri, etkileşimli öğrenme ortamları ve çeşitli okumalarla süreci ilerletmektedirler. Her altı haftada bir öğretmenlerin bitirme projesi teslim etmeleri ve bu projelerini sınfflarında uygulamaları gerekmektedir. Bir başka araştırmada, Shaha ve Elisworth (2013) tarafından çevrim içi tartışma ortamlarının ve video izleme etkinliklerinin olduğu bir mesleki gelişim programı tasarlanmış, programa haftada en az üç saat öğretmenlerin aktif olarak katılması 
sağlanmıştır. Bu programda 90 dakikalık video izleme etkinlikleri, öğretmenlerin yansıtma ve paylaşım yapmaları için sistematik olarak hazırlanmıştır. Öğretmenler aynı zamanda kazanım yazma etkinlikleriyle öğretecekleri içeriğe odaklanmıştır. Bu programda öğretmenler arasında iş birliği, çevrim içi platform üzerinden yapılmış ve öğretmenlerin soru sorması ve sordukları sorular üzerine düşünmesi teşvik edilmiştir.

Özetlemek gerekirse, karma modelle yürütülen mesleki gelişim çalışmalarının biçimsel olarak farklar barındırdığı göze çarpmaktadır. Öğretmenlerin mesleki gelişimi düşünüldüğünde, çıktılara bağlı olarak yüz yüze, senkron ve asenkron etkinlik ve materyallerin eklenebildiği ve bu özelliklerin etkili mesleki gelişim sağlamada kullanıldığı görülmektedir. Yukarıda verilen örnekler, etkinliklerin sürece yayılması, aktif öğrenme yaşantılarıyla yürütülmesi ve asenkron yaşantılarla öğrenmenin mekan ve zamandan bağımsız ilerleyebildiğini ortaya koymaktadır. Sonuç olarak, yukarıda belirtildiği gibi, etkili mesleki gelişim programlarında, formattan önce 'etkili özellikler' gelmekte ve bu özelliklere göre tasarlanan mesleki gelişim programlarının öğretmenlere yararlı olabileceği söylenebilmektedir.

\section{Etkili Mesleki Gelişim İçin Bir Program Önerisi}

Yüz yüze, senkron ve asenkron etkinliklerin dengeli karışımı, verim ve ulaşılabilirlik açısından öğretmenlere önemli fırsatlar sunmaktadır (Bohle Carbonell, Dailey-Hebert, ve Gijselaers, 2013; Moskal, Dziuban, ve Hartman, 2013). Bir önceki bölümdeki örneklerde görüleceği gibi, bu yaklaşımla geliştirilen mesleki gelişim programlarında, öğretmenlerin bilgi ve becerilerini arttırmak için etkileşimli yaşantılar, tartışmalar, aktif öğrenme uygulamaları, uzman desteği ve geri bildirim kullanılmaktadır. Buna dayanarak, bu araştırmanın genel amacı, Türkiye'deki öğretmenlere uygun, salgın süreci ve sonrasında öğretmenlere kaliteli mesleki gelişim imkanları sağlayabilecek bir programı önermektir.

Önerilen programa ilişkin detaylar; programın amaçları, programın özellikleri, programın yürütülmesi, programda teknoloji kullanımı ve programın değerlendirilmesi şeklinde alt başlıklarla sunulmuştur.

\section{Programın Amaçları}

Programın temelinde, öğretmenlerin yüz yüze, senkron ve asenkron öğrenme yaşantıları aracılığıyla belirli bir içeriğe ilişkin bilgi ve becerilerinin, planlanmış bir sürece yayılarak ve uzman desteği sağlanarak geliştirilmesi vardır. Thakur (2012) yüz yüze seminerlere ek olarak, asenkron etkinliklerin, ders notlarının, dijital kütüphanelerin ve sanal grup tartışmalarının öğretmenlerin mesleki gelişiminde etkili olabileceğini vurgulamaktadır.

Bu açıdan bakıldığında mevcut çalışmadaki mesleki gelişim programında amaçlar, örnek olarak aşağıdaki şekilde verilebilir. Öğretmenler,

- $\quad$ etkili öğretim tasarımları yapmak için gerekli olan pedagojik bilgileri geliştirebilirler.

- bir tasarım modeline uygun ders/ünite planları hazırlayacak becerileri edinebilirler.

- ders/ünite planları geliştirme aşamasında meslektaşlarıyla iş birliği yapabilir, etkileşimin etkisini fark edebilirler.

Bunu yaparken yüz yüze seminerler, senkron görüşmeler, asenkron kayıtlar, ders notları ve diğer tüm öğrenme bileşenleri bu amaca hizmet edecek şekilde tasarlanabilir. Bu noktada önemli olan, Eğitimde Keşif Araştırmalarını Geliştirme Topluluğu'nun (CADRE) (2017) ifade ettiği üzere, amaçların net bir biçimde ifade edilmesinin ardından, tüm araçların bu amaca hizmet edecek şekilde, öğretmenleri motive edecek, meslektaşlarıyla iş birliği yapmasını sağlayacak, kendi pratiklerine ilişkin öz-değerlendirme yapmasına fırsat verecek ve sürdürülebilir bir mesleki gelişim anlayışına katkıda bulunacak şekilde kurgulanmasıdır.

\section{Programın Özellikleri}

Program genel olarak katılımcı odaklı etkinliklerden oluşmaktadır ve etkinlikler öğretmenlerin kendi aralarında ve bireysel çalışmasını destekleyecek şekilde kurgulanır. Programda öğretmenlerin pasif bir dinleyici olarak konuşmacıyı dinlemeleri yerine, grup çalışmalarına katılmaları, araştırma yapmaları ve akranlarına destek olarak birlikte öğrenmeleri teşvik edilir. 
Salgın Sürecinde ve Sonrasında Öğretmenlerin Mesleki Gelişimi...

Yukarıda bahsedilen geçmiş araştırmalar ve alan yazındaki diğer çalışmalar (Darling-Hammond ve diğerleri., 2017; Dash ve diğerleri, 2012; Desimone, 2009; DuFour, 2004; Landry ve diğerleri, 2009; Moore ve diğerleri, 2016; Shaha ve Elisworth, 2013; Timperley ve diğerleri, 2007) göz önünde bulundurulduğunda, öğretmenlerin öğrenme sürecine ilişkin kuramsal çalışmalarla uyumlu olacak şekilde programda şu özellikler bulunmaktadır:

- 70 güne yayılmaktadır. Öğretmen bu süre zarfında yüz yüze, senkron ve asenkron etkinlikleri tamamlar. Buradaki temel nokta, öğretmenlerin kendi hızlarında zaman ve mekandan bağımsız olarak çalışmalarını sağlayabilmektir. Öğretmenler her gün mesleki gelişim için bir şeyler yapmasa da asenkron etkinlikler aracılığıyla adım adım öğrenme gerçekleştirirler.

- En az 60 saat öğretmenin canlı ve asenkron etkinliklere katılmasını içermektedir. Öğretmenlerin mesleki gelişim programında oldukları sürece etkinliklere belirli bir zaman harcamaları gerekir. Salgın sürecinde öğretmenlerin video konferans şeklinde atölyelere katılması bu zamanın içindedir. Örneğin, bir ödevi tamamlamak için önce bir saatlik makale okuma ve daha sonra ödevi yazmak için iki saat harcayabilirler. Böylece bir etkinlik öğretmenin farklı günlere yayılan toplam üç saatlik çalışmasıyla tamamlanır.

- Pedagoji bilgisini (örneğin, öğretim strateji ve yöntemleri ve program geliştirme), pedagojik alan bilgisini (örneğin, belirli bir dersi öğretme yöntemleri) ve öğrencilerin nasıl öğrendiği bilgisini (örneğin, aynı seviyedeki öğrencilerin ortak özellikleri) ya da alan bilgisini (örneğin biyoloji konularından hücre) kapsamaktadır. Bu açıdan bakıldığında, programda yer alan içerik çeşitlendirilmekte ve alan yazında önerilen dört içerik çeşidinden en az üçüne hitap edilmektedir.

- Aktif öğrenme yaşantıları içermektedir. Programın sunduğu aktif öğrenme yaşantıları bağlamında öğretmenler birebir deneyim elde etmektedirler. Örneğin, öğretmenler ders planı tasarlayabilir, yeni yöntem ve teknolojileri derslerine dahil edebilir ve bu tasarımları sınıflarında deneyip, uygulayabilirler. Bu uygulamalar hem uzman desteğiyle hem de aynı zümredeki diğer öğretmenlerle yapılır. Burada gerçekleşen mesleki öğrenme bağlamla, yani okulla iç içe girer (Croft ve diğerleri, 2010). Bu noktada, işle bütünleşik öğrenme başlar ve bu tür bir öğrenme, öğretmenlerin deneyimledikleri sınıf ve öğrencileriyle doğrudan ilişkili bir noktaya gelir.

- İş birliğine odaklanmaktadır. Bu programda, öğretmenler, aynı zümre ya da sınıf seviyesindeki diğer öğretmenlerle yapılandırılmış ya da yarı yapılandırılmış iş birliği yapmaktadır. Yapılan bu iş birliği, bilginin ve farklı bakış açılarının, üzerinde çalışılan ortak görevler aracılığıyla paylaşılmasını sağlamaktadır (Darling-Hammond ve diğerleri, 2017). Bu bağlamda örneklendirme yapılacak olursa, öğretmenler ders planlarını zümreleriyle birlikte önceden planlanmış toplantılar aracılığıyla tasarlarlar. Bu toplantılar sürecin ve çıtıların adım adım belli olduğu öğrenme protokolleriyle yürütülmekte ve öğretmenlerin fikirlerini paylaşması ve okul içindeki dinamikleri dikkate alarak ortaklıklar kurması özendirilmektedir. Bahsedilen tüm bu süreçteki amaç, DuFour'un (2004) da ifade ettiği gibi, öğretmenlerin organik öğrenme toplulukları oluşturmaları ve kolektif amaçlarına hep birlikte ulaşmaya çalışmalarıdır. Bu açıdan bakıldığında, iş birliği aynı okul içinde, bir zümrede ve benzer seviyelerde senkron araçların kullanımıyla yapıldığından kolektif katılım sağlanmaktadır.

- En iyi örneklerin gösterimi ve analizi yapılmaktadır. Bu programda, öğretmenlere daha önceden yapılmış, hazır örnekler gösterilmektedir. Öğretilecek her yöntem ve tekniğin ya da planın daha önce başka bir öğretmen tarafından hazırlanmış en iyi hali sunulmakta ve öğretmenlerin bu örnekleri incelemeleri istenmektedir. Buna ek olarak, öğrenci örnekleri, kaydedilmiş ders anlatımları ve yazılı yansıtmalar öğretmenlerle paylaşılmaktadır. Uzmanlar örnekleri analiz ederek, benzer bir plan ya da örnek geliştirmek için gerekli olan araçları (örgütleyiciler, şemalar ve kolaylaştırıcı grafikler) öğretmene kullandırmaktadır. Bu etkinlikler çoğunlukla zümre toplantılarında yapılmaktadır.

- Uzman desteği planlıdır ve uzmana erişim kolay ve hızlıdır. Programda, yüz yüze buluşmalar dışında, özellikle senkron ve asenkron çevrim içi araçların kullanımıyla, öğretmenler program sırası ve sonrasında uzmanlara ulaşmaktadır. Uzmanlar ve öğretmenler arasında yapıcı geri bildirim dışında, örneğin, belirli stratejilerin paylaşımı ve ders planları hakkında fikir alışverişi yapılmaktadır. Bu paylaşımlar, öğretmenin bireysel ihtiyaçlarının karşılanmasına destek olmaktadır. Özellikle ders 
planlarına asenkron video yoluyla verilen geri bildirimler, uzmanlar ve öğretmenler arasındaki iletişim kanallarını açmaktadır.

- Yansıtma ve geri bildirim için özel zaman ayrılmaktadır. Öğretmenler mesleki gelişimlerini, kendi kazanımlarını düşünerek ve bunları paylaşarak sürdürmektedir. Bunun en belirgin örneği, zümre toplantılarında yapılan kısa paylaşımlarda görülmektedir. Geri bildirim kadar önemli olan bir diğer konu da yansıtmadır. Mesleki gelişim programlarında öğretmenlerin öğrenme süreçleri üzerine düşünmesi ve yansıtma yapması, öğrenmenin ve gruba aidiyetin devamlılığı açısından önemlidir (Timperley ve diğerleri, 2007). Zümre toplantılarının ve ders planlarının tamamlanması sonrası, öğretmenlerin öğrenmeleri ve süreç hakkında yansıtma yapmaları programın ayrılmaz bir parçasıdır. Bu yolla öğretmenlerin gelişimi uzmanlar tarafından takip edilmekte ve eksik noktalara ilişkin destek sağlanmaktadır. Geri bildirim, hem uzmanlar hem öğretmenler arasında, öğrenmeyi kolaylaştırıcı bir mekanizmadır. Ders planları öncelikle öğretmenlere dağıtılmakta ve rubrikler aracılığıyla her plan akran değerlendirmesinden geçmektedir. Öğretmenler değişiklikleri yaparak, uzmanlardan da geri bildirim istemektedir. Her plan geri bildirim döngüsünden çıktıtan sonra uygulanmaya hazır hale gelmektedir.

Programın yukarıda bahsedilen özelliklerine ek olarak, bağlamın ve içeriğin izin verdiği durumlarda, programa birtakım eklentiler de yapılabilmektedir. Klette (2019) derslerde oluşturulan video kayıtlarının öğretmenlerin mesleki gelişimleri için etkili öğrenme kaynakları olduğunu vurgulamakta ve öğretimin kalitesini geliştirdiğini ifade etmektedir. Buna örnek olarak, öğretmenler mesleki gelişim programı sırasında hazırladığı ders planlarını sınıflarında yüz yüze ya da uzaktan uygulamakta ve bu dersler ya da derslerin bir kısmı videoyla kaydedilmektedir. Öğretmenler her dersten sonra yapılandırılmış sorulara cevap vererek, biten dersin etkisi ve nasıl gittiğiyle ilgili görüşlerini paylaşmaktadır. Video kayıtları ve yansıtma yazıları, zümre toplantılarında kullanılmak üzere saklanmaktadır. Ayrıca, değerlendirme bölümünde de bahsedileceği üzere, toplanan bu kayıtlar, programın etkisini araştırmak için de kullanılmaktadır.

\section{Programin Yürütülmesi}

Bahsi geçen tüm özelliklerin hayata geçmesini kolaylaştırmak için, önerilen program okulda/işte mesleki gelişim (job-embedded professional development) yaklaşımı (Croft ve diğerleri, 2010) kullanılarak uygulanabilir ve yürütülebilir. Bu yaklaşımda mesleki gelişim, öğretmenin günlük yaşantısına dahil edilmekte ve okul tabanlı bir süreç takip edilmektedir. Öğretmenlerin, çeşitli etkinliklerle birlikte çalışmaları, sınıf içi uygulamalarını değerlendirmeleri ve birbirlerine geri bildirim sunmaları, işte mesleki gelişim yaklaşımının temelinde yer almaktadır. Bu yönüyle, öğretmen okul içinde hem öğrenen hem öğreten rolünü senkron olarak üstlenmektedir (Darling-Hammond ve diğerleri, 2017). Şekil 1'de önerilen programın uygulanma yaklaşımı yer almaktadır:

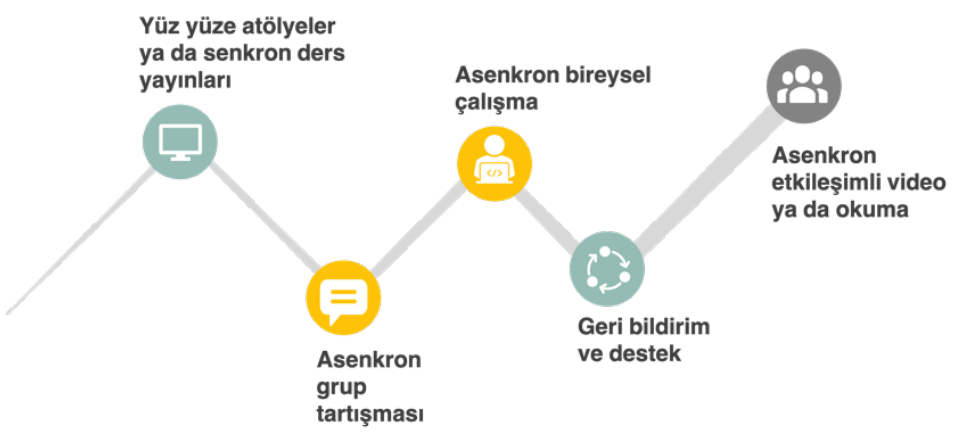

Şekil 1. Önerilen Programın Uygulanma ve Yürütülme Yaklaşımı

Şekil 1'de görüldüğü üzere, programda, öğretmenlerin günlük yaşamında mesleki gelişimlerini sürdürebilmeleri için yüz yüze ve asenkron etkinlikler planlanmıştır. Yüz yüze ya da senkron derslerle başlayan süreç devamında, asenkron etkinlikler ve geri bildirimle öğretmenler mesleki gelişimlerine devam etmektedir. Canlı derslerden sonra olan etkinlikler, okulda mesleki gelişim ilkeleriyle uyumludur. Öğretmenler zaman ve mekandan bağımsız bireysel ve iş birlikli öğrenme gerçekleştirebilir. Süreç her ne 
Salgın Sürecinde ve Sonrasında Öğretmenlerin Mesleki Gelişimi...

kadar doğrusal gözükse de aslında bazı etkinlikler genele yayılabilir. Örneğin, asenkron grup tartışması, canlı dersle birlikte başlayıp bir haftaya yayılarak tamamlanabilir.

Önerilen programın başlangıç noktası, salgın öncesi dönemde kullanılabilir olan yüz yüze atölyelerdir. Yüz yüze atölyeler, öğretmenlerin uzmanlarla bir araya geldiği, belirlenen eğitim içeriği kapsamında fiziki ortamda çalışmalar yaptığı etkinliklerdir. Yüz yüze atölyelerde kuramsal bilgi aktarımı yapılabildiği gibi, bu aktarımın atölye çalışmalarıyla desteklenmesi de sağlanmaktadır. Böylece öğretmenler, pasif bir dinleyici olmak yerine, kendilerine sunulan örnekleri incelemekte, analiz etmekte ve branşları doğrultusunda zümrelerindeki takım arkadaşlarıyla kendi örneklerini geliştirebilmektedir. Fishman ve diğerleri (2013) çevrim içi içeriğin bir yansıması olacak şekilde tasarlanan yüz yüze atölyelerin, öğretmenlerin programa oryantasyonunun yapılmasında etkili olduğunu vurgulamaktadır. Pandemiyle birlikte, yüz yüze atölyelerin, video konferans araçları kullanılarak, senkron olarak ilerletilmesi mümkün görünmektedir. Yüz yüze uygulamalar için planlanan etkinliklerin, çalışma odası ve çeşitli dijital araçlar (Web 2.0 araçları vb.) kullanılarak, benzer şekilde yürütülmesi mümkündür.

Diğer taraftan asenkron etkinlikler, öğretmenlerin hem bireysel hem takımla çalışmalarını gerektiren, öğretim ve öğretim tasarımıyla ilgili öğrenme yaşantılarını içermektedir. Dede ve diğerleri (2009) asenkron programların, öğretmenlerin yoğun programlarıyla daha kolay uyum sağladığını ve öğretmenler için gerçek zamanlı, işe dahil edilmiş bir destek sunduğunu belirtmektedir. Bu şekliyle programdaki mesleki gelişim sadece okul dışındaki eğitimlerle sınırlı kalmamakta, öğretmenler işlerinin bir parçası olarak mesleki gelişimlerini sürdürmektedir. Önerilen programda, yüz yüze atölyelerin içinde ya da hemen sonrasında bireysel olarak tamamlanması gereken ödevler bulunmaktadır. Ödevler çoğunlukla, yüz yüze ya da senkron atölyelerdeki temel bilgi ve becerilerin kullanılmasını gerektiren, uygulamaya yönelik etkinliklerdir. Bu etkinlikler aracılığıyla, öğretmenler atölyede elde ettikleri kazanımları uygulama (deneyerek kendini test etme) ve bunlar hakkında düşünme imkanı bulmaktadır. Bunlara ek olarak, asenkron etkileşimi sağlamak adına, etkileşimli videolar ve sosyal okuma araçları da kullanılmaktadır. Etkileşimli videolarda Playposit ve benzeri araçlar kullanılarak, eğitmen tarafından çekilen videolara, çeşitli noktalarda açık ya da kapalı uçlu sorular eklenmektedir. Videoyu izleyen öğretmenler, videoda karşılarına çıkan sorulara cevap vermektedir. Açık uçlu sorulara verilen cevaplar yoluyla, katılımcılar diğer katılımclarla etkileşime girmektedir. Burada önemli olan, katılımcıların örneklerini paylaşması ve yansıtma yapmasıdır. Benzer şekilde, Perusall gibi sosyal okuma uygulamaları sayesinde, öğretmenler farklı zaman ve farklı mekanlarda aynı okuma parçası ya da makaleyi okuyabilmektedir. Her okumada çeşitli sorular ve yorumlarla etkileşim sağlanmakta, böylece katılımcıların birbirlerinden öğrenmesi desteklenmektedir.

Öğrenme etkinliklerinden sonra, öğrenme toplulukları oluşturma ve bu toplulukları sürdürme, önerilen programın uygulanmasında önemli yer tutmaktadır. Belirli bir amacı yerine getirmek ya da bir hedefe ulaşmak için öğretmenlerin planlı buluşmaları, öğrenme topluluğu olarak tanımlanabilir (DuFour, 2004). Öğrenme toplulukları yüksek bir kalite ile tasarlanıp uygulandığında, öğrencilerin öğrenmelerine olumlu katkıda bulunacağı gibi, öğretmenlerin sınıf içi uygulamalarındaki gelişimi de destekler. Önemli olan, bu toplulukların işte mesleki gelişim formatının benimsemesi ve öğretmenlerin aktif, iş birlikçi ve yansıtıcı bir çerçevede topluluğun üyesi olmasıdır (Darling-Hammond ve diğerleri, 2017). Öğrenme topluluklarında iş birliği ve aktif öğrenme yaşantıları yüz yüze, senkron ya da asenkron gerçekleştirilebilir. Bu noktada, programın takibini yapan uzmanların bu görüşmelere bir odak noktası belirlemeleri ve öğrenme protokolleriyle süreci takip etmeleri önemlidir.

Asenkron etkinlikler, programın uygulanmasında zamandan bağımsız yapıdadır. Asenkron etkinlikler öğretmenlerin zaman konusunda daha esnek olmasını sağlayarak, kendi hızlarında ilerlemelerine ve zaman yönetimini kendi kontrollerinde tutmalarına destek olan etkinliklerdir (Fishman ve diğerleri, 2013). Bu etkinlikler uygulamada çok önemlidir ve programın tam anlamıyla bir parçasıdır.

Programın genel yapısına bakıldığında, yüz yüze ve çevrim içi etkinliklerin oranı içeriğe göre değişiklik gösterecek şekilde planlanabilmektedir. Örnek uygulamalar şu şekilde olabilmektedir: Yüz yüze ya da senkron atölyelere ağırlık verecek program uygulamalarında, temel becerilerin bu etkinliklerde sunulması ve 
asenkron etkinliklerde uygulama ve pekiştirme yapılması gerçekleştirilebilir. Bu durumda \%60 oranında yüz yüze ve $\% 40$ oranında asenkron etkinlikler kullanılabilir. Diğer yandan, yüz yüze atölyelerin ve asenkron etkinliklerin dengesi düşünüldüğünde, bilgi aktarımı, grup çalışmaları ve uygulamalı etkinliklerin programa eşit bir şekilde yayılmasıyla \%50-\%50 oranında yapılabilmesi mümkün olabilmektedir.

Programın uygulanabilirliği ve verimli bir şekilde sonuç elde edilebilmesi için, uygulama ekibine ihtiyaç duyulmaktadır. Bu ekipte en az bir alan uzmanı ve bir mesleki gelişim uzmanı yer alması önemlidir. $\mathrm{Bu}$ uzmanlar programın yürütülmesi dışında, öğretmenlere geri bildirim vermekte ve canlı atölyeleri ilerletmektedir. Buna ek olarak, iki mentör öğretmenin (en az 10 yıldır öğretmenlik yapan ve mesleki gelişim programlarında çalışmaya devam eden) ve bir eğitim teknoloğunun (öğretmenlik yapmayıp, sadece teknoloji kullanımı ve entegrasyonu alanlarında öğretmenlere ve projelere destek sunan) ekipte yer almasının, programın yürütülmesinde verimliliği artırdığı düşünülmektedir. Formatör öğretmenler, öğretmenlerle birebir çalışmakta ve zümre toplantılarına katılmaktadır. Ayrıca formatör öğretmenler asenkron etkinliklerde, aktif katılımın teşvik edilmesi ve grup moderatörlüğü yapılması işlerini üstlenmektedir. Eğitim teknoloğu, öğrenme yönetim sisteminin (ÖYS, Learning Management System - LMS) yönetimi, içeriklerin ÖYS'ye aktarılması ve teknik sorunların çözümü konusunda süreçte destek sunmaktadır.

\section{Programda Teknoloji Kullanımı}

Programda, mesleki gelişim, çevrim içi ortamda, zamandan ve mekandan bağımsız bir şekilde yürütülmektedir. Programın öğretmenlere ulaştırılması tek bir teknolojik araç kullanılarak yapılabilmektedir. $\mathrm{Bu}$ araç, tüm öğrenme yaşantıları, ödev ve katılım bilgilerinin depolandığı bir ÖYS üzerinden yapılmaktadır. Erener (2017) ÖYS'nin çevrim içi içeriğin tasarımı konusunda stil birliği sağladığını ve öğretmenlerin öğrenme sürecinde bir arada olmasına olanak sağlayan bir sistem, hatta sanal bir sınıf olduğunu vurgulamaktadır. ÖYS'nin önemli işlevlerinden biri de öğrenme kalitesini iyileştirilmeye ve etkileşimli bir öğrenme sistemi oluşturmaya olanak sağlamasıdır (Kasim ve Halid, 2016).

Önerilen program, daha önce Türkiye'de üç farklı okulda pilot uygulama olarak yürütülmüştür (Yurtseven ve Doğan, 2020). Programın ÖYS'deki görünümü ve yürütülmesi hakkında fikir vermesi amacıyla, Canvas isimli ÖYS'den birtakım görseller alınmıştır.

Şekil 2'de programının içeriğinin ÖYS'ye göre nasıl geliştirildiği görülmektedir. İki modül (öğrenme birimi) olarak yapılan pilot uygulamada, öğretmenler için dijital bir sınıf oluşturulmuş ve programın organizasyonu ÖYS üzerinden yapılmıştır. Öğretmenler ana menüden asenkron etkinliklere ulaşabilmektedir.

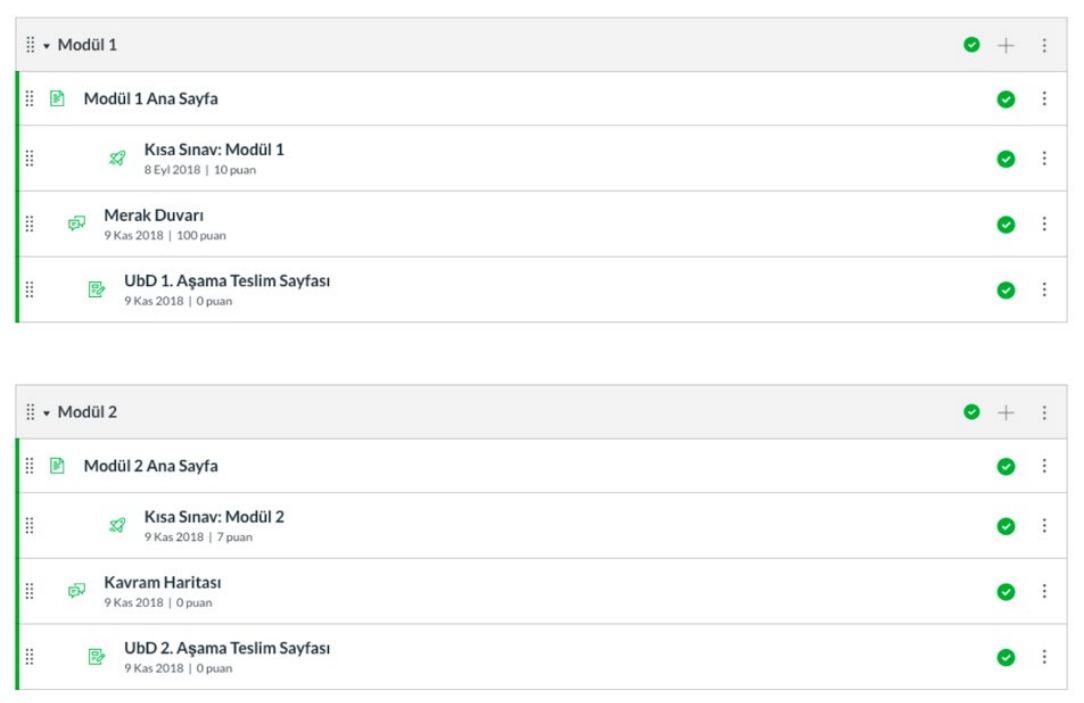

Şekil 2. Canvas'ta Modül Örnekleri

Şekil 3'te programın uygulanmasında bahsedilen kısa sınav ve ödevlere örnek verilmiştir. Bu görselde, 
öğretmenlerin bireysel olarak yüz yüze bir atölyeden sonra, konuları kavrama düzeylerini ölçmek için aldıkları bir kısa sınav yer almaktadır.

\section{Kısa Sınav: Modül 1}

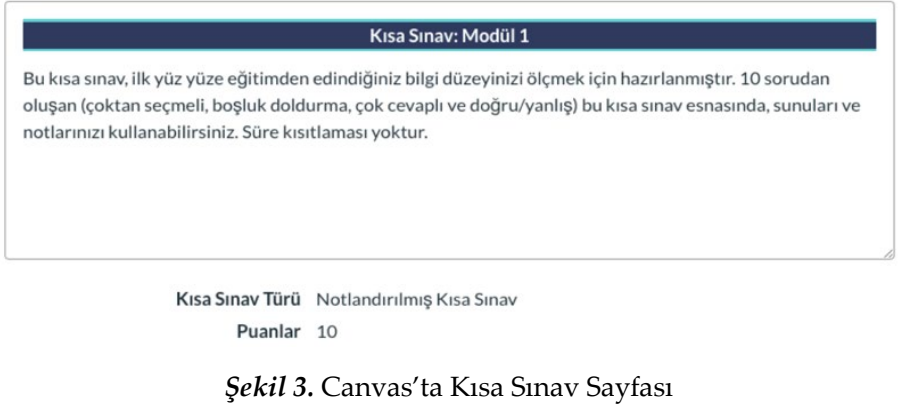

ÖYS ayrıca öğretmenlerin takip edilmesi için öğrenme analitiği sunmaktadır. Öğrenme analitiği temelinde, dijital parmak izlerinden oluşan verilerdir. $\mathrm{Bu}$ veriler ÖYS'de çeşitli kategorilere göre ayrılmaktadır. Eğitmen, öğretmenleri bu verileri kullanarak takip edebileceği gibi performansları hakkında da bilgi sahibi olmaktadır.

Daha kapsamlı bir ifadeyle, öğrenme analitiği, McKenney ve Mor'un (2015) belirttiği gibi, öğrenenlere ve öğretmenlere performansları hakkında gerçek zamanlı geri bildirim sağlama ve öğrenme koşullarını optimize etme noktasında program tasarımcılarına tanılayıcı bir geri bildirim sağlar. Öğrenme analitiği sadece ödev ve etkinliklerin puanlarının tutulduğu bir karneden daha fazlasını ifade etmektedir. Bunlar arasında, öğretmenin sisteme ne zaman girdiği, materyaller ve etkinlikler için ne kadar süre harcadığı, hangi sayfalara baktığı ve videoların ne kadarını izlediği gibi veriler bulunmaktadır (Bkz. Şekil 4 ve 5). Bu veriler kullanılarak, öğrenmenin biçimlendirici değerlendirilmesi yapılmakta ve geri kalan öğretmenlere ihtiyaç duyulan destek sağlanmaktadır.

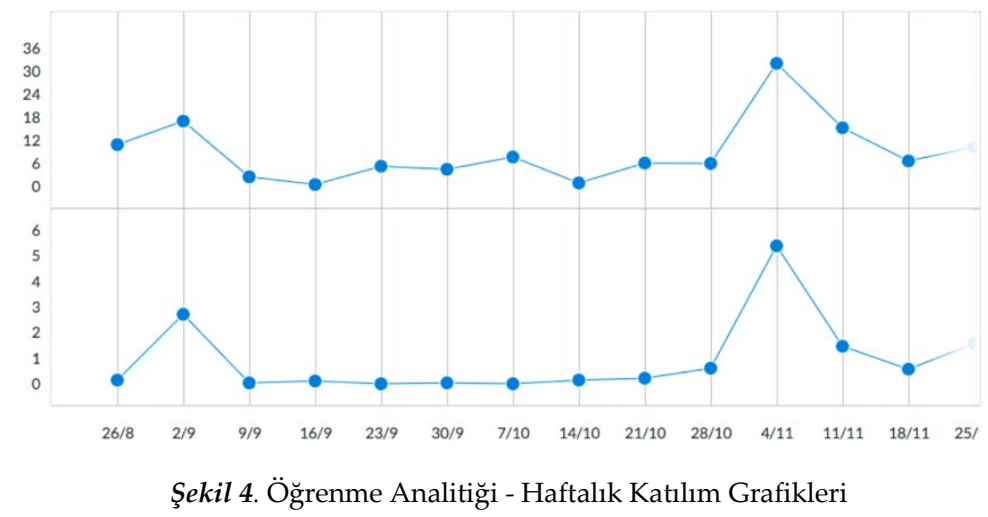

Şekil 4'teki grafik, öğretmenlerin haftalara göre sayfaları açma ve etkinliklere ortalama olarak katılma sayılarını vermektedir. Bu grafik kullanılarak, öğretmenlerin mesleki gelişim programındaki durumları incelenebilmektedir. Örneğin, ilk grafikte öğretmenlerin Canvas ortamına giriş tarihleri belirlenmiştir. 4 Kasım tarihinde öğretmenler Canvas dersindeki etkinliklere daha çok katılmış, $11 \mathrm{Kasım}$ tarihiyle beraber katılımda düşüş yaşanmıştır. Bu veri, öğretmenlerin etkinliklerdeki aktif olma durumuyla ilgili genel bir resim sunmaktadır. Eğitmenler etkinliğin sürekliliği için, etkinlik formatını ya da içeriğini değiştirmeyi düşünebilir.

\begin{tabular}{lccccccc} 
Students (28) . & Grade & $\begin{array}{c}\text { \%On } \\
\text { Time }\end{array}$ & $\begin{array}{l}\text { Last } \\
\text { Participation }\end{array}$ & $\begin{array}{l}\text { Last Page } \\
\text { View }\end{array}$ & $\begin{array}{l}\text { Page } \\
\text { Views }\end{array}$ & Participations \\
\hline B & $\% 100$ & $\% 75$ & 31 Ara 2018 & 31 Ara 2018 & 125 & 10 \\
\hline & $\% 95$ & $\% 75$ & 30 Kas 2018 & 7 Mar 2019 & 201 & 16 \\
\hline
\end{tabular}


Şekil 5'te, öğretmenlerin notlarını, etkinliklere katılım yüzdesini, en son bir etkinliğe katılım tarihini, en son bir sayfayı ziyaret etme tarihini, toplam sayfa açma sayısını ve etkinliklere katılım sayısını gösteren bir görsel görünmektedir (Öğretmen bilgileri gizlenmiştir). Bu bilgi öğrenme analitiği ve öğretmenlerin mesleki gelişimi bakımından önemlidir. Örneğin, BO koduyla derste olan öğretmen, ödevlerinin \%75'ini zamanında teslim etmiş ve genel notu da tamdır. Bu öğretmen, etkinliklere 10 kere katılmıştır. Bu veriyi kullanarak belirli zaman aralıklarında öğretmenlerin performansı, grubun ortalama performansına göre değerlendirilebilir. Katılımı düşük olan öğretmenlerin, süreçte aktif olmadığı anlaşılabilir. Bu durumlarda, öğretmenlere destek sunularak, programda tekrar aktif olmaları sağlanabilir.

Programın uygulanması sürecinde yüz yüze ve asenkron etkinlikler arasında bir denge sağlanarak, öğretmenlerin yüz yüze bir araya gelmesini gerektirmeyecek çalışmaları zaman ve mekandan bağımsız bir şekilde kendilerinin yapması sağlanmaktadır. Çünkü programda odak noktası, öğretmenlere yeni iş yükleri tanımlamak yerine, mesleki gelişimlerini etkili bir şekilde ve optimum sürede devam ettirmelerini sağlamaktır (CADRE, 2017; Galaczi ve diğerleri, 2018). Bu açıdan bakıldığında, zümre toplantıları, atölye çalışmaları, geri bildirim ya da planlama konusunda yüz yüze çalışmayı gerektirecek herhangi bir kritik adımda uzmanlar ya da takım arkadaşlarıyla bir araya gelmek öğretmenlerin programdan tatmin edici düzeyde fayda elde etmelerine imkan sağlamaktadır.

\section{Programın Değerlendirilmesi}

Mevcut mesleki gelişim programı için üç tür değerlendirme yöntemi kullanılabilmektedir. Bu yöntemler aracılığıyla mesleki gelişimin programının etkisi de ayrıca araştırılabilmektedir. Değerlendirme yöntemlerinden birincisi, yukarıda da bahsedildiği üzere ÖYS'nin sunduğu öğrenme analitiği ve bununla ilişkili verilerin, programın değerlendirilmesi için kullanılmasıdır. Örneğin, programdaki etkinliklerin uzmanlar tarafından değerlendirilmesi sonucu oluşturulan puanlar, bu verilerden bazılarıdır. Programda, kısa ödev, grup tartışması, akran değerlendirme performansı ve bireysel ödevler olmak üzere dört etkinlik rubrikler aracılığıyla puanlanmaktadır. Her öğretmen katılımının niteliği ve niceliğine göre etkinliklerden puan almaktadır. Bir diğer veri kaynağı, öğretmenlerin ÖYS'deki hareketlerini ve buradalıklarını gösteren takip verisidir. Bu veri çeşidinde öğretmenin sisteme ne zaman girdiği, sistemde ne kadar kaldığı, sayfalarda ne kadar zaman harcadığı, verilen okumaları ne kadar sürede yaptığı, uzun vadede sisteme giriş frekansı, hangi öğretmenlerle etkileşimde olduğu, etkinlikleri tamamlama süresi ve genel olarak sistemdeki aktifliği rapor edilmektedir. ÖYS'de bu verilere bireysel ve grup olarak sistemin içinde bakılabileceği gibi verilerin dışarı aktarılması ve daha ileri istatistiksel analiz ve incelemelerin yapılması da mümkündür (Bkz. Şekil 4 ve $5)$.

Programa ilişkin değerlendirme yöntemlerinden ikincisi, yüz yüze, senkron ve bireysel asenkron etkinliklerle birlikte öğretmenlerin açık uçlu sorulara yazdıkları yansıtma yazılarıdır. Yansıtma yazıları, biçimlendirici değerlendirmenin bir parçasıdır. Black ve William'a (2009) göre biçimlendirici değerlendirme öğrenenlerin öğrenme süreçleri hakkında formel ve informel yollarla bilgi toplamak için kullanılabilir. Bu değerlendirme biçimi, öğretmenlerin bu yöntemleri kendi sınıflarında gelecekte uygulayabilmeleri açısından da önemlidir. Bu yansıtma yazıları biçimlendirici değerlendirmeye uygun şekilde, öğretmenin her adımda hem kendi gelişimini, hem öğrenme sürecini, hem de sürece ilişkin fikirlerini paylaşmasını içermektedir. Programda, yansıtma yazıları bireysel olarak alınarak, uzmanlar tarafından incelenmektedir. Fakat uzmanlar bu yansıtma yazılarına bir puan atamamakta ya da öğretmen soru sormuyorsa geri bildirim vermemektedir. Yansıtma yazıları, mesleki gelişim sürecinin akışı hakkında bilgi sunacağı gibi, öğretmenlerin öğrenmelerindeki eksiklikleri tespit etmek için de kullanılmaktadır. Örneğin, yansıtma yazılarında pedagojik bilgi eksikliklerinin olduğunu belirten öğretmenler için asenkron video görüşmeleri yapılarak, öğretmenin süreçten kopması engellenmekte ve öğrenmeye destek olunmaktadır.

Üçüncü değerlendirme yöntemi, uzmanların katılmadığı öğrenme amaçlı yapılan zümre toplantılarından ortaya çıkan dokümanlar üzerinden yapılır. Bu toplantılar, grup dinamiğinin ortaya çıkarılması, ihtiyaç noktalarına desteğin sunulması, okul iklimi ve grup kültürünün geliştirmesi için kullanılmaktadır. Öğretmenlerin zümre toplantıları sırasında ve sonrasında tamamladıkları dokümanlar olan toplantı notları, 
Salgın Sürecinde ve Sonrasında Öğretmenlerin Mesleki Gelişimi...

toplantılara ait video ya da ses kayıtları ve uzmanlar tarafından hazırlanan çalışma kağıtlarıdır. Öğrenme topluluğu oluşturma ve bireysel öğrenme sağlama sürecinde bu dokümanlar önem arz etmektedir. Programın yapısında yer alan öğretmenler arası iş birliğinin ortaya çıkıp çıkmadığı, bu değerlendirme yöntemi kullanılarak incelenmektedir.

\section{Sonuç ve Tartışma}

COVID-19 salgını öncesi, öğretmenlerin mesleki gelişimi 'seminer dönemi' ya da 'hizmet içi eğitim zamanı' olarak bilinen, geleneksel yöntemlerle sağlanmaktaydı. Bu dönemlerde verilen eğitimler çoğunlukla, bir konuşmacının önceden belirlenmiş bir konuyu dinleyici olan öğretmenlere aktarması şeklinde ilerlemekteydi. Salgın sırasında, benzer yöntemler değişmemiştir ve 'hizmet içi eğitimler' sadece teknolojik alt yapı kullanılarak 'uzaktan eğitim' yöntemleriyle 'webinar' adı altında düzenlenmeye devam etmiştir. Şüphesiz ki sadece salgın sürecinde yaşanmayan geleneksel yöntemlerle öğretmenin pasif olarak katıldığı bu eğitimler, modern ve yenilikçi anlayışla kıyaslandığında, verimlilik, yararlılık ve kullanışlılık açısından sorgulanmaya başlamıştır.

$\mathrm{Bu}$ sorgulama sonucunda, salgın sırasında öğretmenlerin uzaktan eğitim sürecine daha fazla aşina oldukları düşünülerek, mesleki gelişim programlarında da yeni bakış açılarının değerlendirilmesi gerektiği ortaya çıkmıştır. Bu nedenle mevcut çalışma, halihazırda dünyada aktif olarak uygulanan senkron ve asenkron bileşenlerle oluşturulmuş bir mesleki gelişim programının, salgın sürecinde öğretmenleri destekleyebileceği fikrinden yola çıkmıştır. Son yıllarda bu tür mesleki gelişim alternatiflerine duyulan ihtiyaç, COVID-19 salgınıyla birlikte daha da belirgin hale gelmiştir.

\section{Programın Salgın Süreci ve Sonrasında Uygulanabilirliği}

Salgın sürecinin öğretmenlerin mesleki gelişimlerini sürdürmek amacıyla yüz yüze bir araya gelmesi konusunda bir risk oluşturması, iyi planlanmış, araştırmalarla desteklenmiş özellikleri barındıran ve uzaktan eğitim araçlarıyla zenginleştirilmiş mesleki gelişim programlarına olan ihtiyacı daha da belirgin hale getirmiştir. Salgın sırasında ve sonrasında programın uygulanmasının aşağıda sıralanan çeşitli avantajları beraberinde getireceği düşünülmektedir.

Program, yapısı ve özellikleri sayesinde öğretmenlerin kendi hızlarında çalışmalarına imkan tanımaktadır. Salgının öğretimin devam ettiği süreçte meydana geldiği ve öğretmenlerin uzaktan eğitime hazırlık konusunda normalden daha yoğun günler geçirdiği düşünüldüğünde, mesleki gelişimin esnek bir yapıda sürdürülebilmesi önem arz etmektedir. Programda, her öğretmen bir eğitim materyalini ya da ödevini, teslim tarihine sadık kalmak koşuluyla, istediği zamanda ve ihtiyaç duyduğu süre boyunca çalışarak bitirebilmektedir.

Program, öğretmenlerin zaman ve mekandan bağımsız çalışmalarını mümkün kılan özelliklere sahiptir. Salgın öncesi, mesleki gelişim programları için öğretmenlerin önceden belirlenmiş gün ve saatlerde bir mekanda toplanması gerekmekte ve programlar bunun üzerine kurulmaktaydı. Fakat programın bu özelliği, salgın sırasında, bir mekanda toplanma riski göze alınmadan, öğretmenlerin mobil uygulamalar aracılığıyla program içeriğini görüntüleyebilmesini ve asenkron etkinliklere katkı yapabilmelerini mümkün kılmaktadır. Programın yüz yüze boyutu, salgın sonrasında ya da riskin en aza indiği durumlarda kullanılabileceği gibi, yüz yüze boyutun yerini, ihtiyaca göre senkron etkinlikler alabilir.

Programda bir ÖYS kullanması, öğretmenlerin süreçteki takibi açısından önemlidir. Salgın sürecinde sadece video konferans üzerinden yapılan mesleki gelişim programlarına göre, önerilen programda öğretmen dijital izler bırakmaktadır. Sürdürülebilir bir öğrenme ortamı için, ÖYS' deki bu bilgiler, öğretmenleri motive etme ve programa devam etme konusunda kullanılabilir.

Programın etkileşimli etkinliklere izin veren yapısı öğretmenlerin kendi aralarında iş birliği, fikir alışverişi ya da informel mesleki sohbetler yapmalarına fırsat tanımaktadır. Bu etkinliklerden alınan olumlu sonuç, iş birliği ve benzer etkinliklerin, senkron ve asenkron yollarla da yürütülebileceğini göstermektedir. Diğer bir deyişle, Program, bu mesleki etkinliklerin salgın sırası ve sonrasında, yüz yüze dışında senkron ya da 
asenkron yollarla yapılabileceğini ihtimalini güçlendirmektedir. Canvas gibi ÖYS alternatiflerinin mesajlaşma ve tartışma özellikleri, öğretmenlerin öğrenme topluluğu oluşturmasına yardımcı olmaktadır. Öğretmenler yüz yüze bir araya gelmeden de iş birliği yapabilmekte ve farklı zamanlarda ortak görüşmeler gerçekleştirebilmektedir. Bu fırsatlar, hem öğretmenlerin programdaki birlikteliğini arttırmakta hem de programın çıktılarını daha verimli ve etkili hale getirmek için kullanılmaktadır.

\section{Yazar(lar)ın Beyanı}

Araştırmacıların katkı oranı beyanı: Fikirler, oluşturulan mesleki gelişim programının önerisi ve makale yazımı, yazarların ortak katkısıyla tamamlanmıştır.

Etik Kurul Kararı: Çalışma alan yazın taramaya yönelik bir çalışma olduğundan, etik kurul izni gerekmemektedir.

Çatışma beyanı: Çatışma yoktur.

Destek ve teşekkür: Destek ve teşekkür yoktur.

\section{Kaynaklar}

Akgün, M., \& Atıcı, B. (2017). Ters-düz sınıfların öğrencilerin akademik başarısı ve görüşlerine etkisi. Kastamonu Ĕ̆itim Dergisi, 25(1), 329-344.

Arslan, H. \& Şahin, İ. (2013). Hizmet içi eğitimlerin video konferans sistemiyle verilmesine yönelik öğretmen görüsleri. Journal of Instructional Technologies and Teacher Education, 2 (2), 34-41.

Baran, B. \& Çağlltay, K. (2006). Teachers' experiences in online professional development environment. Turkish Online Journal of Distance Education, 7(4), 110-122.

Belland, B. R., Burdo, R. \& Gu, J. (2015). A blended professional development program to help a teacher learn to provide one-to-one scaffolding. Journal of Science Teacher Education, 26(3), 263-289.

Bilasa, P. \& Taş̧ınar, M. (2017). Hayat boyu öğrenme kapsamında anahtar yeterliklerin belirlenmesi: Türkiye için durum analizi. Milli Ĕ̆itim, 215, 129-144.

Black, P. \& Wiliam, D. (2009). Developing the theory of formative assessment. Educational Assessment, Evaluation and Accountability, 21(1), 5-31.

Bohle Carbonell, K., Dailey-Hebert, A. \& Gijselaers, W. (2013). Unleashing the creative potential of faculty to create blended learning. The Internet and Higher Education, 18, $29-37$.

Buckner, M. (2020). Pivoting professional development through the framework of digital transformation. Educause Review. 10 Kasım 2020 tarihinde https:/er.educause.edu/blogs/2020/6/pivoting-professionaldevelopment-through-the-framework-of-digital-transformation adresinden erişildi.

Croft, A., Coggshall, J. G., Dolan, M., Powers, E. \& Killion, J. (2010). Job-embedded professional development: What it is, who is responsible, and how to get it done well. 20 Kasim 2020 tarihinde https://files.eric.ed.gov/fulltext/ED520830.pdf adresinden erişildi.

Darling-Hammond, L., Hyler, M. E. \& Gardner, M. (2017). Effective teacher professional development. California: Learning Policy Institute.

Dash, S., Magidin de Kramer, R., O’Dwyer, L. M., Masters, J. \& Russell, M. (2012). Impact of online professional development or teacher quality and student achievement in fifth grade mathematics. Journal of Research on Technology in Education, 45(1), 1-26.

Dede, C., Ketelhut, D. J., Whitehouse, P. \& McCloskey, E. (2009). A research agenda for online teacher professional development. Journal of Teacher Education, 60(1), 8-19.

Desimone, L. M. (2009). Improving impact studies of teachers' professional development: Toward better conceptualizations and measures. Educational Researcher, 38(3), 181-199. 
Salgın Sürecinde ve Sonrasında Öğretmenlerin Mesleki Gelişimi...

DuFour, R. (2004). What is a professional learning community? Schools as Learning Communities, 61(8), 6-11.

Eğitimde Keşif Araştırmaları Derneği (CADRE - Community for Advancing Discovery Research in Education). (2017). Emerging design principles for online and blended teacher professional development in K-12 STEM education. 11 Kasim 2020 tarihinde http://cadrek12.org/resources/emerging-design-principlesonline-and-blendedteacher-professional-development-k-12-stem adresinden erişildi.

Erener, E. (2017). Assessing the design and development of hybrid linked learning professional development programs for teachers: Challenges and successes (Yayımlanmamış Doktora Tezi). California State University, California.

Ewing, J. (2020). Teachers in the pandemic. 1 Kasım 2020 tarihinde https://www.forbes.com/sites/johnewing/2020/04/17/teachers-in-the-pandemic/\#49ea0cf88646 adresinden erişildi.

Fishman, B., Konstantopoulos, S., Kubitskey, B. W., Vath, R., Park, G., Johson, H. \& Edelson, D. C. (2013). Comparing the impact of online and face-to-face professional development in the context of curriculum implementation. Journal of Teacher Education, 64(5), 426-438.

Foster, E. (2020). Three lessons learned from the pandemic about professional learning. 2 Kasım 2020 tarihinde https://learningforward.org/2020/07/three-lessons-learned-from-the-pandemic-about-professionallearning/?MvBriefArticleId=23587 adresinden erişildi.

Galaczi, E., Nye, A., Poulter, M. \& Allen, H. (2018). Teacher professional development. 2 Kasım 2020 tarihinde https://www.cambridgeenglish.org/Images/539683-perspectives-teacher-professional-development.pdf adresinden erişildi.

Graham, C. R. (2013). Emerging practice and research in blended learning. M. G. Moore (Ed.), Handbook of distance education (s. 333-350) içinde. ABD: Routledge.

Gürdoğan, M., \& Bağ, H. (2019). Harmanlanmış uygulamalarin akademik başari, Motivasyon ve öğrenci görüşlerine etkisi. Akdeniz Üniversitesi Ĕ̆itim Fakültesi Dergisi, 2(1), 36-61.

Hebebci, M. T. \& Usta, E. (2015). Türkiye'de harmanlanmış öğrenme eğilimleri: Bir literatür çalışması. Adryaman Üniversitesi Sosyal Bilimler Enstitüsü Dergisi, 8(19), 195-219.

Ilaria, D. (2017). The efficacy and impact of a hybrid professional development model on handheld graphing technology use. Contemporary Issues in Technology and Teacher Education, 17(2), 194- 204.

İlğan, A. (2013). Öğretmenler için etkili mesleki gelişim faaliyetleri. Uşak Üniversitesi Sosyal Bilimler Dergisi, 4156.

İlğan, A. (2020). Öğretmenler için etkili mesleki gelişim yaklaşımları ile bir model önerisi ve uygulama önerisi. Ĕ̆itim ve Insani Bilimler Dergisi, 11(21), 171-197.

Kasim, N. N. M. \& Halid, F. (2016). Choosing the right learning management system (LMS) for the higher education institution context: A systematic review. International Journal of Emerging Technologies in Learning, 11(6), 55-61.

Kaufman, J. H. (2020). Three steps to make learning more equitable should schools close again this Fall. 1 Kasım 2020 tarihinde https://www.rand.org/blog/2020/06/three-steps-states-could-take-to-make-sure-learning.html adresinden erişildi.

Klette, K. (2019, Ekim). Towards a common language for teaching? The role of curriculum and instruction around the world? 7. Eğitim Programları ve Öğretim Kongresi, Ankara.

Korucu, A., \& Kabak, K. (2020). Türkiye'de hibrit öğrenme uygulamaları ve etkileri: Bir meta analiz çalışması. Bilgi ve İletişim Teknolojileri Dergisi , 2(2), 88-112.

Landry, S. H., Anthony, J. L., Swank, P. R. \& Monseque-Bailey, P. (2009) Effectiveness of comprehensive professional development for teachers of at-risk preschoolers. Journal of Educational Psychology, 101(2), 448- 
465.

McKenney, S. \& Mor, Y. (2015). Supporting teachers in data-informed educational design. British Journal of Educational Technology, 46(2), 1-15.

Moore, M., Robinson, H. A., Sheffield, A. \& Phillips, A. S. (2017). Mastering the blend: A professional development program for K-12 teachers. Journal of Online Learning Research, 3(2), 145-173.

Moore, S., Haviland, D., Moore, W. \& Tran, M. (2016). Preparing teachers to use GIS: The impact of a hybrid professional development program on teachers' use of GIS. Journal of Science Education ve Technology, 25(6), 930-946.

Moskal, P., Dziuban, C. \& Hartman, J. (2013). Blended learning: A dangerous idea? The Internet and Higher Education, 18, 15-23

Owston, R. D. Sinclair, M. \& Wideman, H. (2008). Blended learning for professional development: An evaluation of a program for middle school mathematics and science teachers. Teacher College Record, 10(5), 1033-1064.

Penuel, W. R., Roschelle, J. \& Shechtman, N. (2007). Designing formative assessment software with teachers: An analysis of the co-design process. Research and Practice in Technology Enhanced Learning, 2(1), 51-74.

Putnam, R. T. \& Borko, H. (2000). What do new views of knowledge and thinking have to say about research on teacher learning? Educational Researcher, 29(1), 4-15.

Reimers, F., Schleicher, A., Saavedra, J. \& Tuominen, S. (2020). Supporting the continuation of teaching and learning during the COVID-19 Pandemic: Annotated resources for online learning. 2 Kasım 2020 tarihinde https://www.oecd.org/education/Supporting-the-continuation-of-teaching-and-learning-during-theCOVID-19-pandemic.pdf. Organisation for Economic Co-operation and Development adresinden erişildi.

Rossett, A. (2002). The ASTD e-learning handbook: Best practices, strategies, and case studies for an emerging field. USA: McGraw-Hill Trade.

Shaha, S. H. \& Ellsworth, H. (2013). Predictors of success for professional development: Linking student achievement to school and educator successes through on-demand, online professional learning. Journal of Instructional Psychology, 40(1), 19-26.

Sosyal Medya ve Dijital Güvenlik Eğitim Araştırma Merkezi (SODİMER). (2021). Dijital öğretmen okulu. 10 Kasım 2020 tarihinde https://sodimer.org/dijitalogretmenokulu/yonerge.html adresinden erişildi.

Spencer, G. (2020). Schools after COVID-19: From a teaching culture to a learning culture. 10 Kasim 2020 tarihinde https://news.microsoft.com/apac/features/technology-in-schools-from-a-teaching-culture-to-a-learningculture/ adresinden erişildi.

TEDMEM. (2019). TALIS 2018 sonuçları ve Türkiye üzerine değerlendirmeler (TEDMEM Analiz Dizisi 6). Türk Eğitim Derneği Yayınları.

Thakur, G. R. (2012). Asynchronous learning and professional development. 10 Kasim 2020 tarihinde https://www.researchgate.net/publication/327012000_Asynchronous_Learning_and_Professional_Devel opment adresinden erişildi.

Timperley, H., Wilson, A., Barrar, H. \& Fung, I. (2007). Teacher professional learning and development. 10 Kasim 2020 tarihinde http://www.oecd.org/education/school/48727127.pdf adresinden erişildi.

Töre, E. (2017). Öğretmenlerin mesleki gelişimi için atölye çalışması modeline dayalı bir uygulamanın geliştirilmesi ve değerlendirilmesi. Marmara Üniversitesi Atatürk Ĕğitim Fakültesi Ĕ̆itim Bilimleri Dergisi, 46(46), 133-150.

Yıldız, M. \& Arkan, Z. (2019). Arapça öğretmenleri mesleki gelişimi ve Startalk Arapça öğretmeni mesleki gelişim programı. Araştırma ve Deneyim Dergisi, 4(1), 1-20. 
Salgın Sürecinde ve Sonrasında Öğretmenlerin Mesleki Gelişimi...

Yurtseven, N. \& Dogan, S. (2020, Nisan) Cultivating designer teacher role through a hybrid professional development program. American Education Research Association. San Francisco, CA. http://tinyurl.com/so5vgzs (Konferans iptal edilmiştir). 


\section{EXTENDED ABSTRACT}

\section{Introduction}

The COVID-19 outbreak affected all the world, daily life and all professional groups, as well as the teaching profession. As a result of the spread of the pandemic in full swing in many parts of the world, educational activities were suspended for a while, the semester break was rescheduled for a week earlier in Turkey and distance education started after one week of break. Although no preparation was made before, online education started with the inclusion of distance education tools in all institutions with an emergency action plan. This dramatic change has led to a major change in teachers' daily routines, teaching styles and, of course, their professional development processes. All over the world, teachers, as one of the most important stakeholders of education systems, have started to use some digital tools that were not widely used as part of their teaching and professional development during the pandemic process. As Kaufman (2020) states, these changes were like "putting together the plane while flying" and teachers were making great efforts to adapt to this change at a dizzying pace for the continuation of teaching and professional development. Moreover, there was no example of a model that could be utilized while going through this process of change (Reimers et al., 2020).

The need for effective professional development programs for the continuation of the professional development of teachers and the continuity of education is very clear, and there has been a serious growth in the field of hybrid learning in recent years. However, there are very few studies on the adaptation of different hybrid learning alternatives for the professional development of teachers or on the examination and introduction of the adapted models. Research in the literature draws attention to this gap (Bilasa ve Taşpınar, 2017). Despite having been 7-8 months since the first outbreak and there have been efforts in all sectors, it is observed that hybrid professional development models for teachers in Turkey are not at the sufficient level to meet the expectations. The current research is important in terms of describing how the professional development process of teachers can be shaped during the pandemic process with a hybrid professional development model and how this model can be used in the future for the professional development of teachers.

\section{Continuing the Professional Development of Teachers with Hybrid Model}

The basis of the model is the development of teachers' knowledge and skills regarding a specific content through live and asynchronous learning experiences by spreading to a planned process and providing expert support. For example, in a professional development program prepared according to this model, teachers can develop the pedagogical knowledge required to design effective teaching and acquire the skills to prepare lesson/unit plans suitable for a design model.

The model generally consists of participant focused activities. It is planned in a way to support teachers' work among themselves and individually. Instead of passive listening, teachers are encouraged to participate in group work, do research, and learn together by supporting their peers.

In the model, face-to-face and online activities are planned for teachers to continue their professional development in their daily life. The first element of the proposed model is the face-to-face workshops available in the pre-pandemic period. Face-to-face activities are activities where teachers come together with experts and work in a physical environment within the scope of the pre-determined educational content. Theoretical knowledge can be transferred in face-to-face work, and this transfer is supported by workshops. Thus, instead of being a passive listener, teachers can examine and analyze the examples presented to them and develop their own examples with their teammates in line with their branches. Online activities include learning experiences related to teaching and instructional design, which require teachers to work both individually and in teams. In this way, professional development in the model is not limited to training outside of school, but continues professional development as a part of the teaching job.

The second element of the proposed model is mostly individually completed assignments and quizzes that should be completed within or immediately after face-to-face workshops. Through these activities, 
teachers have the opportunity to try and think about the acquisitions they have achieved in the workshop.

The third element of the proposed model is learning communities. Planned meetings of teachers to fulfill a specific purpose can be defined as a learning community. In addition, collaborative and active learning experiences in learning communities can take place face to face or asynchronously. What is important here is that experts set a focal point for these interviews and move the process forward with learning protocols.

The fourth element of the proposed model is asynchronous activities. These activities are a core element and are fully part of the model. Learning is carried out online, regardless of time and space. Delivery of the model to teachers can be done using a single technological tool. This tool is made over a learning management system (LMS) where all learning experiences, assignments and participation information are stored.

\section{Conclusion}

The pandemic has affected the whole world and all professions as well as the teaching profession with important changes and new requirements. It is obvious that such a situation would have negative reflections on teachers', their teammates' and students' success as it is not possible to think of a teacher independent of the professional development process. The pandemic process poses a risk for teachers to come together face to face in order to maintain their professional development is a fact and this has made the need for wellplanned hybrid professional development proams that have research-supported features and enriched with distance education tools more clear. In the forthcoming period, using the current research model and similar hybrid professional development models will prevent teachers' professional development from being negatively affected by this process and will contribute to the professional development process. 